\title{
Color-coded Imaging of the Fate of Cancer-cell-derived Exosomes During Pancreatic Cancer Metastases in a Nude-mouse Model
}

\author{
TOMOYUKI SATAKE $^{1}$, ATSUSHI SUETSUGU ${ }^{1,2,3}$, MIKI NAKAMURA ${ }^{1}$, TAKAHIRO KUNISADA ${ }^{1}$, \\ SHIGETOYO SAJI ${ }^{1}$, HISATAKA MORIWAKI ${ }^{1}$, MASAHITO SHIMIZU ${ }^{1}$ and ROBERT M. HOFFMAN ${ }^{2,3}$ \\ ${ }^{1}$ Gifu University Graduate School of Medicine, Gifu, Japan; \\ ${ }^{2}$ AntiCancer, Inc., San Diego, CA, U.S.A.; \\ ${ }^{3}$ Department of Surgery, University of California, San Diego, CA, U.S.A.
}

\begin{abstract}
Background/Aim: Tumor-derived exosomes play important roles in tumor metastases. In this report, we observed the fate of tumor-derived exosomes in pancreatic cancer metastatic nude-mouse models using color-coded imaging. Materials and Methods: Mia-PaCa-2 human pancreatic cancer cells expressing red fluorescent protein (RFP) were transduced by exosome-specific $p C T$-CD63-green fluorescent protein (GFP) and injected in the spleen of nude mice. Results: Four weeks after injection of these cells into the spleen, liver metastases developed and tumor-derived exosomes were observed within the metastatic cancer cells and in Kupffer cells. Furthermore, tumor-derived exosomes diffused to bone marrow and lung cells, especially macrophages, without any metastases present. Conclusion: In the present study, we visualized the distribution of cancer-derived exosomes for the first time at the cellular level, in a pancreatic-cancer metastatic model.
\end{abstract}

Exosomes are small membrane vesicles of approximate 30$150 \mathrm{~nm}$ in diameter (1). Tetraspanins, such as CD9, CD63, and CD81, are enriched in the membrane of exosomes and serve as exosomal markers (2). Exosomes contain bioactive molecules including DNA, mRNA, microRNA, and proteins

This article is freely accessible online.

Correspondence to: Atsushi Suetsugu, MD, Ph.D., Department of Gastroenterology, Gifu University Graduate School of Medicine, Gifu, Japan, 1-1 Yanagido, Gifu 501-1194, Japan. Tel: +81 582306308, Fax: +81 582306310, e-mail: asue@gifu-u.ac.jp; Robert M. Hoffman, Ph.D., AntiCancer, Inc., 7917 Ostrow Street, San Diego, CA 92111, U.S.A. Tel: +1 8586542555, Fax: +1 8582684175, e-mail: all@anticancer.com

Key Words: Pancreatic cancer, exosomes, tumor-derived exosomes, macrophage, green fluorescent protein, red fluorescent protein, color-coded imaging, nude mice.
(3-5). These components have a role in cell-to-cell communication. Exosomes have an important function in metastasis (6-8). Exosomes derived from tumors and also cancer-associated fibroblasts (CAFs) enhance metastasis. They may also affect angiogenesis, epithelial to mesenchymal transition (EMT), and immune modulation (912). We previously reported that breast-cancer-derived exosomes were incorporated into tumor-associated cells and contributed to developing a metastatic niche visualized by using color-coded imaging (13). Macrophages also have an important role in metastasis. For instance, tumor-associated macrophages (TAMs) have been shown to promote tumor growth in the tumor microenvironment (TME). Tumorderived exosomes have been shown to induce polarization of macrophages, which enhanced tumor metastasis (14-18).

In the present report, we visualized the distribution of tumor-derived exosomes in a pancreatic cancer metastatic mouse model, and observed that tumor-derived exosomes were present in Kupffer cells in the liver, bone marrow and lung without any metastases.

\section{Materials and Methods}

Cell line and culture conditions. Mia-PaCa-2 human pancreatic adenocarcinoma cells, were engineered to stably express red fluorescent protein (RFP) as previously reported (19). The cells were maintained in RPMI 1640 medium (Gibco-BRL, Grand island, NY, USA) supplemented with $10 \%$ heat-inactivated fetal bovine serum (FBS) and $1 \%$ penicillin and streptomycin (Gibco-BRL). The cells were cultured in a humidified atmosphere containing $5 \% \mathrm{CO}_{2}$ at $37^{\circ} \mathrm{C}$.

Lentiviral exosome labeling. Mia-PaCa-2 cells were transduced with lentiviral vector, pCT-CD63-green fluorescent protein (GFP) (System Biosciences, CA, USA), which contains the tetraspanin CD63 gene fused to GFP for tracking exosomes (20).

Mice. All experiments were conducted in accordance with the institutional guidelines of Gifu University, Gifu, Japan, and 
approved by the animal research committee and the committee on living modified organisms of Gifu University (approval number 2637). In order to minimize any suffering of the animals, anesthesia and analgesics were used for all surgical experiments. Animals were anesthetized by subcutaneous injection of a $0.02 \mathrm{ml}$ solution of 20 $\mathrm{mg} / \mathrm{kg}$ ketamine. The response of animals during surgery was monitored to ensure adequate depth of anesthesia. Animals were housed in a barrier facility on a high-efficiency particulate arrestance (HEPA)-filtered rack under standard conditions of 12-h light/dark cycles. Mice were fed with an autoclaved laboratory rodent diet.

Pancreatic adenocarcinoma metastasis model. Balb-c/nu-nu mice ( 8 weeks old) were used as hosts. Mia-PaCa- 2 cells, expressing RFP and transduced with pCT-CD63-GFP, were harvested by trypsinization, washed three times with cold serum-free medium, and then resuspended in serum-free RPMI 1640 medium. MiaPaCa- 2 cells $\left(2.0 \times 10^{6}\right)$ were injected into the spleen of mice. Four weeks later, all the mice were sacrificed and had primary tumors as well as liver metastases. Liver metastases as well as lung and bone marrow were cultured and observed for tumor-derived exosomes by fluorescence imaging.

Tumor imaging. The SZX microscope and FV1000 confocal microscope (Olympus Corp. Tokyo, Japan) were used for imaging.

\section{Results and Discussion}

In order to track the distribution of tumor-derived exosomes, pCT-CD63-GFP (System Biosciences), which contains the tetraspanin CD63 gene fused to GFP was used to transduce Mia-PaCa-2 human pancreatic adenocarcinoma cells expressing RFP. Tumor-derived exosomes were observed with a confocal microscope using color-coded imaging (Figure 1).

Mia-PaCa-2 human pancreatic cancer cells expressing exosome-specific pCT-CD63-GFP were injected into the spleen of Balb-c/nu-nu mice. Four weeks later, all mice were sacrificed. Primary tumor in the spleen (Figure 2A) and multiple metastases in the liver were imaged (Figure 2B). Metastases were not observed in the lung (Figure 2C). Mia$\mathrm{PaCa}-2$ cells in the metastases contained GFP-expressing exosomes (Figure 3A).

Liver metastases as well as lung and bone marrow were cultured to observe tumor-derived exosomes. Interestingly, although there were no cancer cells expressing RFP present, tumor-derived exosomes were observed in bone marrow cells, especially in macrophages (Figure 4B). Kupffer cells derived from the liver contained tumor-derived exosomes (Figure 3B). In addition, tumor-derived exosomes were occasionally observed in lung macrophages without any metastases (Figure 4A).

Tumor-derived exosomes develop a pre-metastatic niche and can determine metastasis (21). Tumor-derived exosomes also have immune suppressive effects and promote metastasis $(22,23)$. On the other hand, tumorderived exosomes from poorly metastatic cells may induce
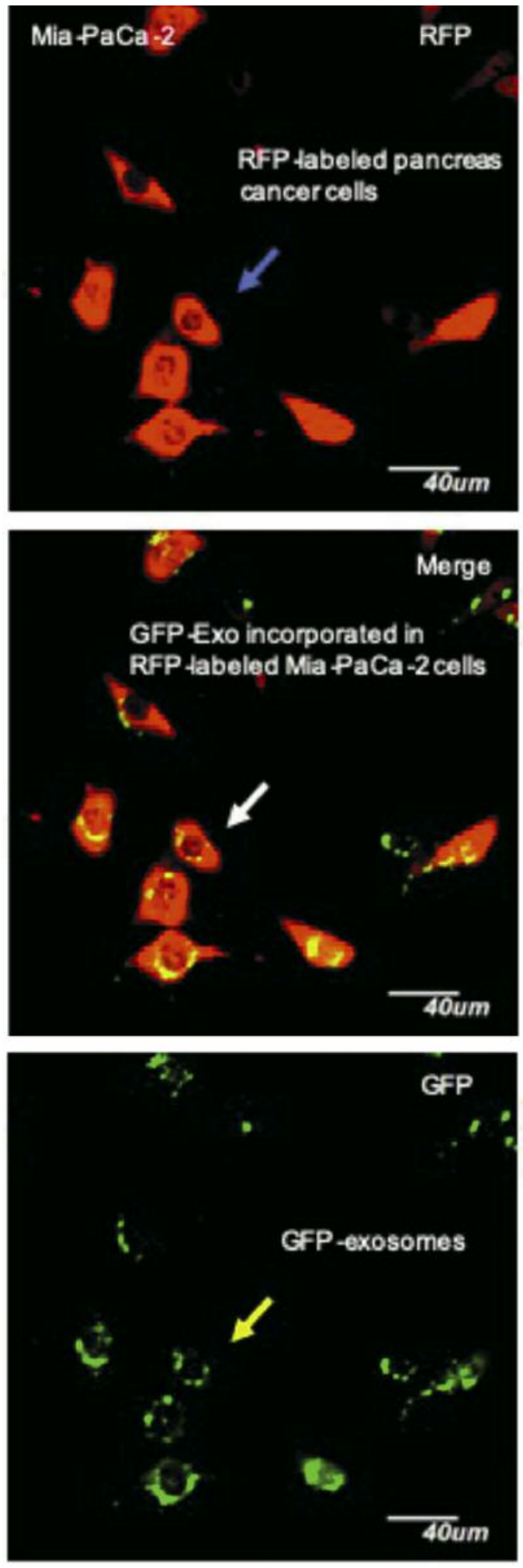

Figure 1. RFP expressing Mia-PaCa-2 cells were transduced with $p C T$ CD63-GFP for tracking exosomes. Blue arrow indicates RFP-labeled pancreatic cancer cells. Yellow arrow indicates GFP-exosomes. White arrow indicates GFP-exosome incorporated in RFP-labeled Mia-PaCa2 cells. $($ Bar $=40 \mu \mathrm{m})$. 

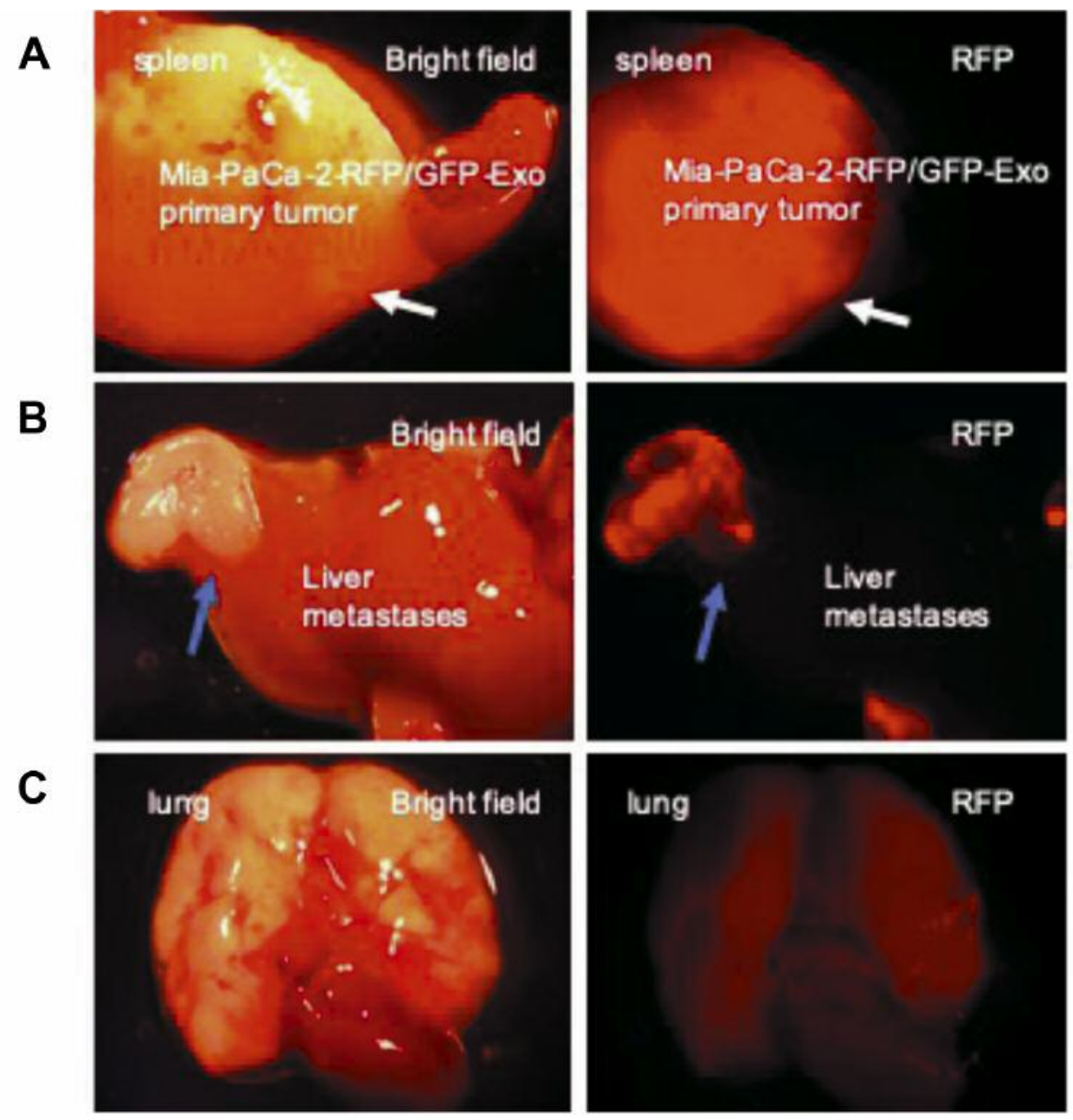

Figure 2. Pancreatic cancer experimental metastases model established with red fluorescent protein (RFP) expressing Mia-PaCa-2 cells with green fluorescent protein (GFP) expressing exosomes. Primary tumor in spleen (white arrow) and metastatic tumors in liver (blue arrows). No metastases in lung.

immune surveillance in the pre-metastatic niche (24). These tumor promoting or suppressing mechanisms of exosomes may be related to bone marrow derived cells, including macrophages. Macrophages are polarized between M1 and M2 phenotypes. M2 macrophages have tumor-promoting effects, while M1 macrophages have tumor-suppressive effects $(15,17)$. In addition, myeloid-derived suppressor cells (MDSC) suppress anti-tumor immunity and promote tumor progression and metastases $(25,26)$. These immunesuppressive functions are related to tumor-derived exosomes. The present report is the first to demonstrate tumor-derived exosomes in both metastatic and nonmetastatic organs in vivo in a tumor-bearing animal.

Further experiments are needed to determine how tumorderived exosomes promote or suppress metastases, and characterize how macrophages are educated by tumorderived exosomes.

\section{Conflicts of Interest}

None of the Authors have any conflicts of interest with regard to this study.

\section{Authors' Contributions}

T.S., A.S., and R.M.H. conceived and planned the experiments. T.S., M.N., and A.S. carried out the experiments. T.S., M.N., A.S., and R.M.H. contributed to the interpretation of the results. All Authors provided critical feedback and helped shape the research and manuscript.

\section{References}

1 Kowal J, Tkach M and Théry C: Biogenesis and secretion of exosomes. Curr Opin Cell Biol 29: 116-125, 2014. PMID: 24959705. DOI: 10.1016/j.ceb.2014.05.004 

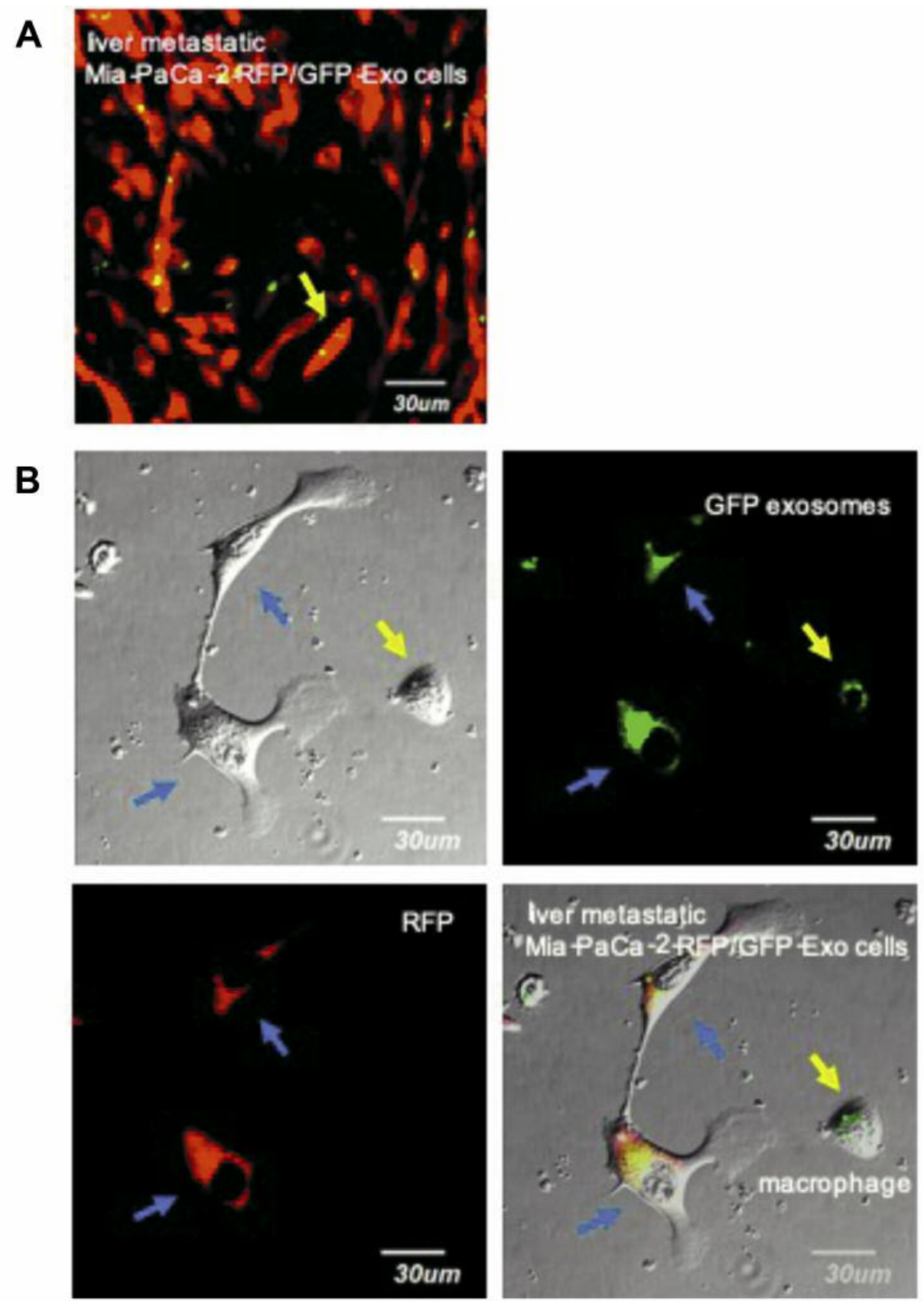

Figure 3. Mia-PaCa-2 cells in liver metastasis contained GFP-expressing exosomes. (A) RFP-labeled Mia-Paca-2 cells producing GFP-labelled exosomes in liver metastases (yellow arrows). GFP expressing exosomes are present in metastasis (Bar=30 $\mu \mathrm{m})$. (B) Blue arrows indicate GFP-exosomes incorporated in RFP-labeled Mia-Paca-2 cells. Yellow arrows indicate macrophages in liver containing tumor-derived exosomes (Bar=30 $\mu \mathrm{m})$.

2 Andreu Z and Yáñez-Mó M: Tetraspanins in extracellular vesicle formation and function. Front Immunol 5: 442, 2014. PMID: 25278937. DOI: $10.3389 /$ fimmu.2014.00442

3 Choi DS, Kim DK, Kim YK and Gho YS: Proteomics, transcriptomics and lipidomics of exosomes and ectosomes. Proteomics 13: 1554-1571, 2013. PMID: 23401200. DOI: 10. 1002/pmic.201200329
4 Thakur BK, Zhang H, Becker A, Matei I, Huang Y, Costa-Silva B, Zheng Y, Hoshino A, Brazier H, Xiang J, Williams C, Rodriguez-Barrueco R, Silva JM, Zhang W, Hearn S, Elemento O, Paknejad N, Manova-Todorova K, Welte K, Bromberg J, Peinado H and Lyden D: Double-stranded DNA in exosomes: a novel biomarker in cancer detection. Cell Res 24: 766-769, 2014. PMID: 24710597. DOI: 10.1038/cr.2014.44 
A
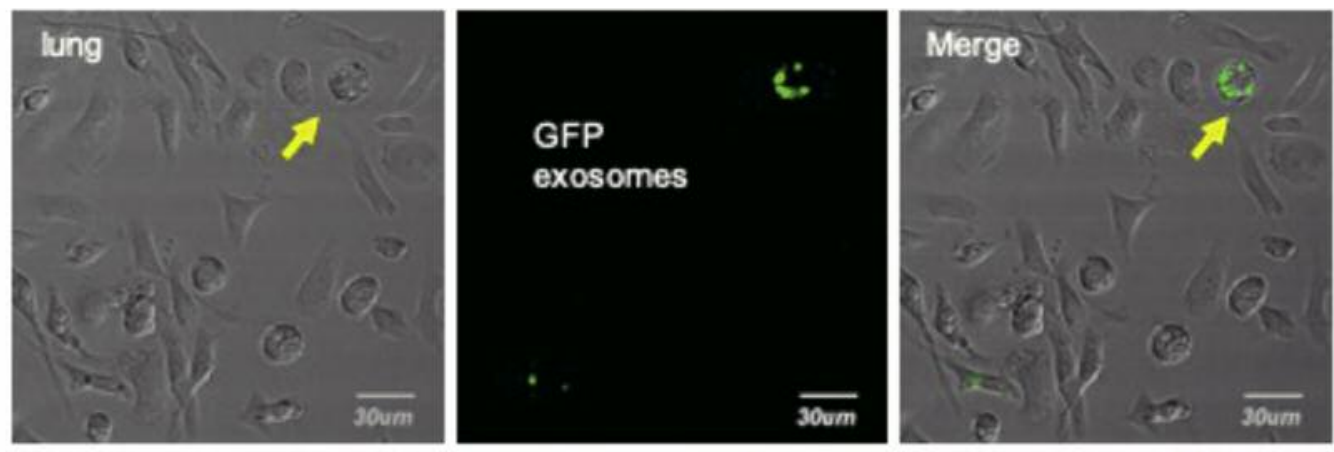

B
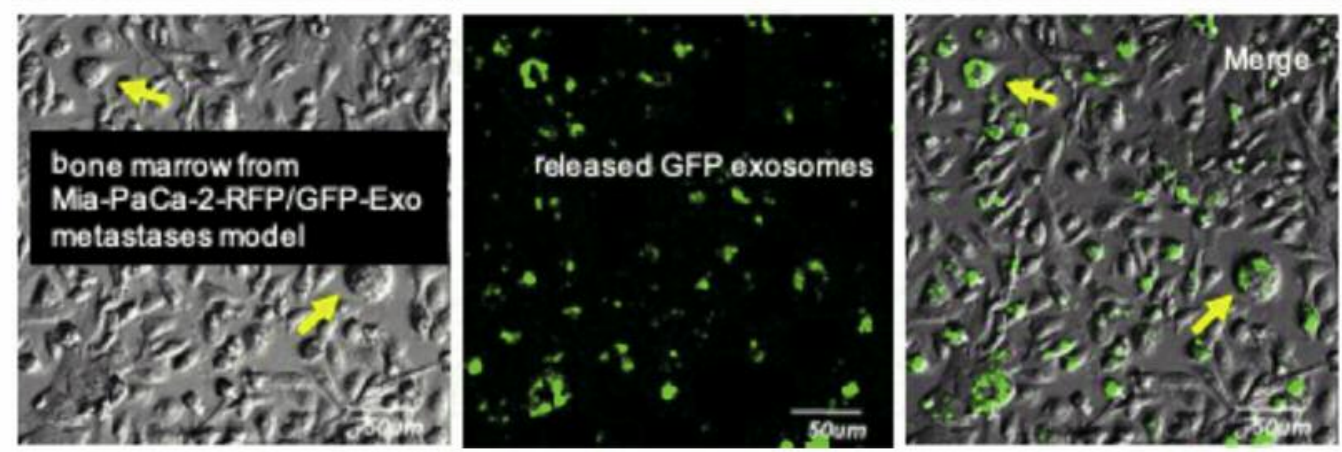

Figure 4. Distribution of tumor-derived exosomes. Yellow arrows indicate macrophages in lung (A) (Bar=30 $\mu m)$ and bone marrow (B) (Bar=50 um) containing tumor-derived exosomes.

5 Valadi H, Ekström K, Bossios A, Sjöstrand M, Lee JJ and Lötvall JO: Exosome-mediated transfer of mRNAs and microRNAs is a novel mechanism of genetic exchange between cells. Nat Cell Biol 9: 654-659, 2007. PMID: 17486113. DOI: $10.1038 /$ ncb1596

6 Becker A, Thakur BK, Weiss JM, Kim HS, Peinado H and Lyden D: Extracellular vesicles in cancer: cell-to-cell mediators of metastasis. Cancer Cell 30: 836-848, 2016. PMID: 27960084. DOI: $10.1016 /$ j.ccell.2016.10.009

7 Peinado H, Lavotshkin S and Lyden D: The secreted factors responsible for pre-metastatic niche formation: Old sayings and new thoughts. Semin. Cancer Biol 21: 139-146, 2011. PMID: 21251983. DOI: 10.1016/j.semcancer.2011.01.002

8 Kahlert C and Kalluri R: Exosomes in tumor microenvironment influence cancer progression and metastasis. J Mol Med 91: 431437, 2013. PMID: 23519402. DOI: 10.1007/s00109-013-1020-6

9 Umezu T, Ohyashiki K, Kuroda M and Ohyashiki JH: Leukemia cell to endothelial cell communication via exosomal miRNAs. Oncogene 32: 2747-2755, 2013. PMID: 22797057. DOI: 10.1038/onc.2012.295

10 Luga V, Zhang L, Viloria-Petit A.M, Ogunjimi AA, Inanlou MR, Chiu E, Buchanan M, Hosein AN, Basik M and Wrana JL: Exosomes mediate stromal mobilization of autocrine Wnt-PCP signaling in breast cancer cell migration. Cell 151: 1542-1556, 2012. PMID: 23260141. DOI: 10.1016/j.cell.2012.11.024

11 Donnarumma E, Fiore D, Nappa M, Roscigno G, Adamo A, Iaboni M, Russo V, Affinito A, Puoti I, Quintavalle C, Rienzo A, Piscuoglio S, Thomas R and Condorelli G: Cancer-associated fibroblasts release exosomal microRNAs that dictate an aggressive phenotype in breast cancer. Oncotarget 8: 19592-19608, 2017. PMID: 28121625. DOI: 10.18632/oncotarget. 14752

12 Peinado H, Alečković M, Lavotshkin S, Matei I, Costa-Silva B, Moreno-Bueno G, Hergueta-Redondo M, Williams C, García-Santos $\mathrm{G}$, Ghajar CM, et al: Melanoma exosomes educate bone marrow progenitor cells toward a pro-metastatic phenotype through MET. Nat Med 18: 883-891, 2012. PMID: 22635005. DOI: 10.1038/nm.2753

13 Suetsugu A, Honma K, Saji S, Moriwaki H and Hoffman RM: Imaging exosome transfer from breast cancer cells to stroma at metastatic sites in orthotopic nude-mouse models. Adv Drug Deliv Rev 65: 383-390, 2013. PMID: 22921594. DOI: 10.1016/j.addr.2012.08.007

14 Wynn TA, Chawla A and Pollard JW: Macrophage biology in development, homeostasis and disease. Nature 496: 445-455, 2013. PMID: 23619691. DOI: 10.1038/nature12034

15 Martinez FO, Sica A, Mantovani A and Locati M: Macrophage activation and polarization. Front Biosci 13: 453-461, 2008. PMID: 17981560.

16 Xue J, Schmidt SV, Sander J, Draffehn A, Krebs W, Quester I, De Nardo D, Gohel TD, Emde M, Schmidleithner L, Ganesan H, Nino-Castro A, Mallmann MR, Labzin L, Theis H, Kraut M, Beyer M, Latz E, Freeman TC, Ulas T and Schultze JL: Transcriptome-based network analysis reveals a spectrum model of human macrophage activation. Immunity 40: 274-288, 2014. PMID: 24530056. DOI: 10.1016/j.immuni.2014.01.006

17 Mantovani A, Sica A, Sozzani S, Allavena P, Vecchi A and Locati M: The chemokine system in diverse forms of macrophage activation and polarization. Trends Immunol 25: 677-686, 2004. PMID: 15530839. DOI: 10.1016/j.it.2004.09.015 
18 Quatromoni JG and Eruslanov E: Tumor-associated macrophages: function, phenotype, and link to prognosis in human lung cancer. Am J Transl Res 4: 376-389, 2012. PMID: 23145206.

19 Katz MH, Takimoto S, Spivack D, Moossa AR, Hoffman RM and Bouvet M: An imageable highly metastatic orthotopic red fluorescent protein model of pancreatic cancer. Clin Exp Metastasis 21: 7-12, 2004. PMID: 15065597.

20 Garcia NA, Ontoria-Oviedo I, González-King H, Diez-Juan A and Sepúlveda P: Glucose starvation in cardiomyocytes enhances exosome secretion and promotes angiogenesis in endothelial cells. PLoS One 10: e0138849, 2015. PMID: 26393803. DOI: 10.1371/journal.pone.0138849

21 Hoshino A, Costa-Silva B, Shen TL, Rodrigues G, Hashimoto A, Tesic Mark M, Molina H, Kohsaka S, Di Giannatale A, Ceder S, Singh S, Williams C, Soplop N, Uryu K, Pharmer L, King T, Bojmar L, Davies AE, Ararso Y, Zhang T, Zhang H, Hernandez J, Weiss JM, Dumont-Cole VD, Kramer K, Wexler LH, Narendran A, Schwartz GK, Healey JH, Sandstrom P, Labori KJ, Kure EH, Grandgenett PM, Hollingsworth MA, de Sousa M, Kaur S, Jain M, Mallya K, Batra SK, Jarnagin WR, Brady MS, Fodstad O, Muller V, Pantel K, Minn AJ, Bissell MJ, Garcia BA Kang Y, Rajasekhar VK, Ghajar CM, Matei I, Peinado H, Bromberg $\mathrm{J}$ and Lyden D: Tumour exosome integrins determine organotropic metastasis. Nature 527: 329-335, 2015. PMID: 26524530. DOI: $10.1038 /$ nature 15756

22 Xiang X, Poliakov A, Liu C, Liu Y, Deng Z, Wang J, Cheng Z, Shah SV, Wang GJ, Zhang L, Grizzle WE, Mobley J and Zhang HG: Induction of myeloid-derived suppressor cells by tumor exosomes. Int J Cancer 124: 2621-2633, 2009. PMID: 19235923. DOI: $10.1002 / \mathrm{ijc} .24249$
23 Wen SW, Sceneay J, Lima LG, Wong CS, Becker M, Krumeich S, Lobb RJ, Castillo V, Wong KN, Ellis S, Parker BS and Möller A: The biodistribution and immune suppressive effects of breast cancer-derived exosomes. Cancer Res 76: 6816-6827, 2016. PMID: 27760789. DOI: 10.1158/0008-5472.CAN-16-0868

24 Plebanek MP, Angeloni NL, Vinokour E, Li J, Henkin A, MartinezMarin D, Filleur S, Bhowmick R, Henkin J, Miller SD, Ifergan I, Lee Y, Osman I, Thaxton CS and Volpert OV: Pre-metastatic cancer exosomes induce immune surveillance by patrolling monocytes at the metastatic niche. Nat Commun 8: 1319, 2017. PMID: 29105655. DOI: 10.1038/s41467-017-01433-3

25 Nagaraj S and Gabrilovich DI: Myeloid-derived suppressor cells. Adv Exp Med Biol 601: 213-223, 2007. PMID: 17713008. DOI: 10.1007/978-0-387-72005-0_22

26 Wang J, De Veirman K, De Beule N, Maes K, De Bruyne E, Van Valckenborgh E, Vanderkerken $\mathrm{K}$ and Menu E: The bone marrow microenvironment enhances multiple myeloma progression by exosome-mediated activation of myeloid-derived suppressor cells. Oncotarget 6: 43992-44004, 2015. PMID: 26556857. DOI: 10.18632 /oncotarget.6083
Received May 14, 2019

Revised June 14, 2019

Accepted June 18, 2019 